\title{
Analysis of Marketing Strategies to Increase Sales at PT. Karya Tunggal Properti
}

\author{
Aidil Amin Effendy \\ Universitas Pamulang \\ Email: dosen00967@unpam.ac.id
}

\begin{abstract}
Innovative and creative marketing strategies must always be carried out so that the company does not experience a loss in sales so that if it is unable to compete with other companies. The purpose of this study was to determine the implementation of the marketing strategy of PT. Karya Tunggal Properti Pamulang Tangerang Selatan and know the implementation of the marketing strategy of PT. Karya Tunggal Properti Pamulang, Tangerang Selatan to increase sales. In this study, the research approach used is to use qualitative methods. Qualitative research is aimed at gaining a deep understanding of the situation at hand. In this study, data collection techniques used in qualitative methods are interviews, observation, and documentation. The research results obtained, namely in general property products managed by PT. Karya Tunggal Properti experienced sales growth from year to year, but the target of the company has not been achieved. The unit sales data obtained are a total of 20 housing units sold from 2017 totaling 8 units and in 2018 totaling 12 units, while the target given by the company is 36 units so that the realization of the percentage obtained only reaches $22.22 \%$ and $33.33 \%$, but sales from 2017 to 2018 increased by $11.11 \%$. The success of increasing sales of PT. Karya Tunggal Properti for 1 year was obtained from the implementation of marketing strategies, including product strategy, price, promotion, and place.
\end{abstract}

Keywords: Anaysis; marketing strategy; sales

\section{INTRODUCTION}

The house is a basic need of every human being because every human being definitely desires to have his or her own home so that daily life that is carried out with the family is safer, more comfortable and peaceful (Mahamud, Abdul Ghani, \& Salleh, 2004; Sulistiyani, 2002; Suprijanto, 2004). Then the thing that becomes a business opportunity of a company engaged in property is competing to win the competition in selling and offering superior housing compared to its competitors (Arifin, 2007; Jaya, Adi, \& Noranita, 2014; Murwanti, 2009). But all that can not be separated how far the marketing strategy is carried out, both in terms of product, price, location, and promotion in winning the competition, even some of the companies that offer more adequate and modern facilities to bring in many potential customers. The aim of the company is for sales to continue to increase consistently (Asmarantaka et al., 2017; Kotler, 2013; Tjiptono \& Chandra, 2018). The optimal effort in preparing a marketing strategy to increase sales is very necessary for the company's sustainability and progress. 


\section{$104 \mid$ Jurnal Office: Jurnal Pemikiran Ilmiah dan Pendidikan Administrasi Perkantoran Vol. 4, No. 2, Juli-Desember 2018, Hal 65-70}

Innovative and creative marketing strategies must always be carried out so that the company does not experience a loss in sales so that if it is unable to compete with other companies, the company will be more easily out of business (Agusrinal, 2014; Azizah \& Adawia, 2018; Kurniawati \& Arifin, 2015; Peter \& Olson, 2014; Sutisna, 2003). For example, when business competitors in the property sector continue to carry out an effective and efficient marketing and offer property products according to the tastes, needs and purchasing power of the people while we are unable to compete, then the company we have will be increasingly left behind with competing companies. So as much as possible we must be able to compete with a variety of marketing strategies and continue to be developed over (Assauri, 2011; Sumarwan, 2003). In marketing management, one of the marketing strategies is how to make the marketing mix or commonly known as the marketing mix are the factors that companies need to be able to bring consumers consistently (Fitriyono \& Khuzani, 2014; Hurriyati, 2005; Tulasi, 2012). The strategy in the marketing mix consists of four components namely product, promotion, price, and place (Kotler, 2013; Lupiyoadi, 2013; Stevenson W.J. Chuong S.C., 2014; Tjiptono \& Chandra, 2018).

In today's competitive and global era, marketing strategies in property businesses must continue to be developed in order to be able to generate profits optimally. Thus, one effective business that is property products must be able to offer different advantages from other competitors, such as more adequate swimming pool facilities, comfortable clubhouses, and different promotions and attract consumers to buy them. PT. Karya Tunggal Properti has not been able to achieve the target expected by the company owner or the company itself, because only $22.22 \%$ and $33.33 \%$ of the targeted target, but year-on-year namely 2017 to 2018 has increased by $11.11 \%$. This is because there are various factors that need to be investigated in order to find solutions such as making marketing strategies more effective so that the company can increase its sales, not go bankrupt and can compete with other competitors.

\section{METHOD}

In this study, the research approach used by researchers is to use qualitative methods. In qualitative research, having a character that is inseparable from observing participation, because the researcher's role determines the overall scenario, then in this study, researchers act as key instruments, full participants as well as data collectors, while other instruments are supporting. (Sugiyono, 2012). The data needed in this study is divided into two types, namely primary data and secondary data. Data collection techniques used are observation, documentation, and interviews. While the data analysis techniques used are data collection, data reduction, data presentation and drawing conclusions

\section{RESULT AND DISCUSSION}

PT. Karya Tunggal Properti is a company engaged in the property sector is a company that offers exclusive dwellings and clusters in the Pamulang area. PT. Karya Tunggal Properti also always develops marketing strategies through product strategy, promotion, price and location or 
Aidil Amin Effendy; Analysis of Marketing Strategies to Increase Sales... 105

place. The business that is often done by PT. Karya Tunggal Properti is conducting promotions in various print and online media consistently and periodically. But in his efforts, PT. Karya Tunggal Properti did not reach the target in selling the target property sold as expected by the company.

\section{Marketing strategy}

The product strategy carried out is very in accordance with the price offered because of PT. Karya Tunggal Properti offers modern and innovative building designs and offers the best building specifications in the same class cluster, including offering concrete foundations, with building structures: reinforced concrete, full red brick walls, roof truss: lightweight steel, ceramic with granite, door designs and aluminum-frame windows, bathroom sanitation with the famous and best brand name "Toto", electrical power installations reaching 2,200 watts and clean water installations: bore wells, semi-spring, with the availability of adequate drainage and pump sources. The uniqueness that is shown in the design from the front of the house is the beautiful carvings and natural stone with modern nuance. In addition to building products, facilities and infrastructure available for housing are the clubhouses and swimming pool which is always clean and comfortable to use.

Price is one of the main considerations of consumers in buying it so that the price strategy offered has been considered and designed according to the market share to be addressed by the company. The pricing strategy was undertaken by PT. Karya Tunggal Properti is by offering a price with the suitability of the design of a guaranteed and modern quality building product. Regarding the price options offered there are several alternative options, namely the Emerald type with a building area of $88 \mathrm{~m}$ and a width of $6 \mathrm{~m}$ front view with a price range starting from the price of 1 billion and above, as well as the new type of Emerald with a slightly different building area of $107 \mathrm{~m}$ and $6 \mathrm{~m}$ wide front view offering a little more expensive than the usual Emerald type. Another more affordable type is the Piresia type with a building area of 69 and a width of $5 \mathrm{~m}$ front view and a new type of Piresia smaller with a building area of 50 and a width of $5 \mathrm{~m}$ front view with a price range starting at 800 million.

In the location or location strategy, PT. Karya Tunggal Properti offers a strategic residence because it is on the Lele Raya main road which can be passed by 2 cars so as to facilitate access to cars in and out. Another strategic location is in the middle of the Pamulang sub-district and near the shopping center, Pamulang Square and Pamulang University campus, even toll-access is close to the Bamboo Prime Residence residential location offered by PT. Single Property Work.

Promotion strategies carried out by PT. Karya Tunggal Properti is considered to be quite varied and is regularly carried out to increase sales. The promotion strategy carried out by PT. Karya Tunggal Properti, based on the results of observations and interviews conducted by researchers, are among others: conventional, namely in the form of printed media such as brochures, banners, pole banners on several electric poles and giant banners that are in the middle of intersections or roundabouts in the middle of the highway; digital marketing is online media, such as Facebook, paid Instagram with the spread of promotions as many as 900012,000 Instagram users, PT's personal website. Karya Tunggal Properti and also promote 


\section{6| Jurnal Office: Jurnal Pemikiran Ilmiah dan Pendidikan Administrasi Perkantoran \\ Vol. 4, No. 2, Juli-Desember 2018, Hal 65-70}

through the website at rumah123 and rumah.com and other forms of digital marketing; exhibition or open a stand in front of the area or in several shopping centers.

In terms of market segmentation and market demand, namely the market segment, consumers of these products are the people of Pamulang and surrounding areas; target market, potential consumers are the upper-middle class in the area of Pamulang and surrounding areas; positioning, PT. Karya Tunggal Properti is very different from other competitors because this company offers more comfortable residential and clusters with very adequate and modern facilities such as a clubhouse and swimming pool.

\section{Analysis of Marketing Strategies to Increase Sales}

In Marketing Strategy Analysis, researchers first analyzed using SWOT analysis, namely analysis in terms of strengths, weaknesses, opportunities, and threats

The strengths of PT Karya Tunggal Properti are the facilities offered by the company PT. Karya Tunggal Properti is very adequate compared to other competing companies in the Pamulang area, namely the availability of clubhouses and swimming pools, both swimming pools for adults and specifically for children. In terms of building design, PT. Karya Tunggal Properti offers building design that is unique, modern and different from other competitors with the quality of the building which is guaranteed quality and quality. The area of the road used by paving blocks which covers an area of more than 2 cars into one road route.

Weaknesses owned by PT. Karya Tunggal Properti is offering a price that is quite expensive when compared to other competitors who are in Pamulang, due to purchasing power or the ability of the community to buy housing at PT. Karya Tunggal Properti is very few considering the Pamulang sub-district the average population is in the middle to lower category. Access to public transport is also not yet available and is a consideration for consumers in purchasing Bamboo Prime Residence housing managed by PT. Single Property Work.

Opportunities exist are companies that only offer safe and comfortable cluster house dwelling by taking up the middle to upper market share. Another opportunity is that the selling price of land in the Pamulang area continues to experience a significant increase in selling prices from year to year.

Threats are the number of competitors offering lower selling prices and access to public places that are closer to the housing offered

From the analysis, it can be concluded that there are considerations in formulating the best marketing strategies effectively and efficiently by looking at the 4 components in the SWOT Analysis.

Looking in terms of the strength of PT. Karya Tunggal Properti is a swimming pool facility that is offered is one of its own advantages offered to consumers, so a consistent and periodic promotion is needed so that people know the Bamboo Prime Residence housing built by PT. Karya Tunggal Properti is located in Pamulang and consumers can visit to make it possible for opportunities to be purchased by consumers who come to increase sales of PT. Single Property Work.

As for the weaknesses, which are relatively expensive prices in the Pamulang area, it must continue to be balanced by offering more adequate facilities and product designs and building 
clusters that are safer and more comfortable. This is expected to increase sales owned by PT. Single Property Work.

Regarding opportunities owned by the company, it can be utilized by PT. Karya Tunggal Properti to continue to bring in consumers significantly to increase existing sales.

Then the threats that exist, must be overcome by the company so that consumers are increasingly convinced to choose and buy housing offered by PT. Karya Tunggal Properti is compared to other houses offered by other companies. All strategies are carried out, especially marketing strategies that are applied in order to increase sales so that the impact on company profits increases.

\section{CONCLUSION}

The marketing strategy is highly favored by PT. Karya Tunggal Properti is a product strategy because of PT. Karya Tunggal Properti offers modern and innovative building designs and offers the best building specifications in the same class as the cluster, in addition to building products, as well as facilities and infrastructure available for housing, namely a clubhouse and swimming pool that is always clean and comfortable to use, even the availability of 2 swimming pools, that is, one for adult swimming pools and one for children. The other strategy's advantages are that of the promotion strategy carried out by PT. Karya Tunggal Properti, with various promotions, including in terms of conventional forms of media, online digital media marketing, and even Instagram that is managed is paid Instagram at a price of 3 million per month with a range of promotion spread of 9000-12,000 Instagram users, also personal websites and promote on other websites, namely at rumah123 and rumah.com as well as exhibitions or open a stand in front of the area or in several shopping centers.

\section{REFERENCES}

Agusrinal, D. D. (2014). Perancangan Strategi Pemasaran Pada Produk Anyaman Pandan. Jurnal Sains, Teknoligi dan Industri.

Arifin, Z. (2007). Ringkasan Penelitian Studi Identifikasi Faktor-Faktor yang Terkait dengan Pertumbuhan Bisnis Perumahan di Sleman. Logika. https://doi.org/10.20885/logika.vol4.iss1.art5

Asmarantaka, R. W., Atmakusuma, J., Pemasaran, K., Yanti, A. :, Muflikh, N., Rosiana, N., ... Pertanian Bogor, I. (2017). Pemasaran. Jurnal Agribisnis Indonesia.

Assauri, S. (2011). Manajemen Pemasaran Dasar Konsep dan Strategi. In PT RajaGrafindo Persada, Jakarta. https://doi.org/10.1109/ACC.2007.4282338

Azizah, A., \& Adawia, P. R. (2018). strategi pemasaran. Cakrawala - Jurnal Humaniora. https://doi.org/10.31294/JC.V18I2.4117

Fitriyono, D., \& Khuzani. (2014). Analisis Pengaruh Bauran Pemasaran Terhadap Volume Penjualan Produk. Jurnal Ilmu \& Riset Manajemen. https://doi.org/10.5281/zenodo.1012560 


\section{8| Jurnal Office: Jurnal Pemikiran Ilmiah dan Pendidikan Administrasi Perkantoran Vol. 4, No. 2, Juli-Desember 2018, Hal 65-70}

Hurriyati, R. (2005). Bauran Pemasaran dan Loyalitas Konsumen. In Alfabeta Bandung.

Jaya, T. S., Adi, K., \& Noranita, B. (2014). Sistem Pemilihan Perumahan dengan Metode Kombinasi Fuzzy C-Means Clustering dan Simple Additive Weighting. JURNAL SISTEM INFORMASI BISNIS. https://doi.org/10.21456/vol1iss3pp153-158

Kotler. (2013). Manajemen Pemasaran Jilid 2. In Penerbit Erlangga.

Kurniawati, D., \& Arifin, N. (2015). Strategi Pemasaran Melalui Media Sosial dan Minat Beli Mahasiswa. Jurnal Manajemen.

Lupiyoadi, R. (2013). Manajemen Pemasaran Jasa: Berbasis Kompetensi Edisi 3. Penerbit Salemba.

Mahamud, R., Abdul Ghani, S., \& Salleh, P. D. A. G. Bin. (2004). Pengaruh Insentif Keatas Pasaran Harta Tanah Perumahan. Pusat Pengajian Perumahan, Bangunan dan Perancangan.

Murwanti, S. (2009). Perilaku Konsumen dalam Memilih Perumahan pada Perumahan Cipta Laras Bulusulur Wonogiri. Jurnal Manajemen dan Bisnis.

Peter, J. P., \& Olson, J. C. (2014). Perilaku Konsumen dan Strategi Pemasaran. In salemba empat.

Stevenson W.J. Chuong S.C. (2014). Manjemen Operasi Perspektif Asia. In 2.

Sulistiyani, A. T. (2002). Problematika dan Kebijakan Perumahan di Perkotaan. ilmu Sosial dan Ilmu Politik.

Sumarwan, U. (2003). Perilaku Konsumen: Teori dan penerapannya dalam Pemasaran. Ghalia Indonesia, Jakarta.

Suprijanto, I. (2004). Reformasi Kebijakan \& Strategi Penyelenggaraan Perumahan \& Permukiman. DIMENSI (Jurnal Teknik Arsitektur). https://doi.org/10.1007/s11010-0089743-3

Sutisna. (2003). Perilaku Konsumen: Teori dan penerapannya dalam Pemasaran. Ghalia Indonesia, Jakarta. https://doi.org/10.1007/BF01013984

Tjiptono, F., \& Chandra, G. (2018). Manajemen Kualitas Jasa. Yogyakarta. ANDI. https://doi.org/10.12691/jbms-4-4-1

Tulasi, D. (2012). Komunikasi Pemasaran. Humaniora. 